Part 4. Studia Iuridica Lublinensia vol. XXVII, 1, 2018

\author{
Bernd Oppermann \\ University of Hanover, Germany \\ oppermann@jura.uni-hannover.de
}

\title{
On the Role of Precedents and Legal Certainty in German Private Law
}

\author{
O roli precedensu i pewności prawa w niemieckim \\ prawie prywatnym
}

\section{SUMMARY}

The article discusses the role of precedents in the German judicial practice. In the European continental tradition, law enactment is within the legislature, whereas the role of the judiciary is to enforce law. In the continental system, precedent does not constitute a source of law sensu stricto, that is, a formal source of law. In order to guarantee the law utility and, ultimately, the legal certainty, courts interpret legal provisions in a unified manner. It is noteworthy that during the recent years the coherent interpretation of legal provisions and, by the same token, the commitment to law development, have increased. That means that a unified interpretation of law performed by courts may be considered a precedent. In this context, precedents and stare decisis have been replacing the logical interpretation of law in German courts.

Keywords: precedent; legal certainty; German legal system; legal method; interpretatio logica

\section{INTRODUCTION}

This article deals with the question about the role of precedents in German legal practice. Formally seen - since doctrines of precedent and of stare decisis are not available - the answer for German law must be plainly negative. In European continental tradition, the production of law is in the competence of the legislative power while judicial power is dedicated to apply of the law ${ }^{1}$. Obviously, however, the legislative power may not and cannot regulate any single issue of the economy,

${ }^{1}$ In C. Montesquieu, De L'esprit des lois, Vol. XI, Ch. 6, the judge appears as the "bouche qui prononce les paroles de la loi". 
the society, of the world for all individual cases. More general rules are the answer if not the notion prevails that abstraction is a predicate of rules as such. Consequently, the question arises for legal certainty and equity in applying the law ${ }^{2}$. A doctrine of precedents is no solution in continental context, resting in a hybrid state of an informal source of $\mathrm{law}^{3}$. Consequently, in continental tradition, the solution was a precise method of interpreting legal rules as applied by national courts in order to achieve uniform interpretation of the law and - ultimately-legal certainty ${ }^{4}$. The details about the way to reach this goal might differ substantially between the EU member states about the issue of interpreting national and European enactments by the courts. Furthermore, the matter of uniform interpretation of the law is of crucial importance in respect of functionality and efficiency of any judicial system. This is to say that in continental context the question for the scope and validity of a theory of precedents ${ }^{5}$ refers to the question for the legal method.

In Germany, the jurisdiction of the grand chamber of the Supreme Court (BGH) relates to legal method insofar as problems of uniform interpretation and (judgemade) development of the law are concerned ${ }^{6}$. In this respect, the jurisdiction of the Supreme Court guarantees a definite degree of legal certainty and equal treatment of similar cases. Furthermore, the topic of consistent interpretation sheds some light onto the role of national supreme courts in their relationship with the European Court in general ${ }^{7}$.

"Legal certainty" may deem to be the product of uniform interpretation of the law achieved through the application of the principle of equality. Precedents are considered in the light of legal method employed by the constitutionally determined function of the judicial power, while they are not determined to be a formal source of law. However, precedents may provide a kind of authoritative example of correct

${ }^{2}$ The notion of certainty relates to precedents, cf. R. Cross, Precedent in English Law, Oxford 1977, p. 108, 134.

${ }^{3}$ H. Fenge, Der Richterspruch als Rechtsquelle, [in:] International Legal Studies, ed. B.H. Oppermann, Bd. 1, Halle 2009, p. 109; F. Müller, R. Christensen, Juristische Methodik, Bd. 1, Berlin 2009, p. 539; W.R. Schluep, Einladung zur Rechtstheorie, Bern 2008, Rn 2475-2516.

${ }^{4}$ L. Bach, L., Répertoire de droit civil, Paris 2009, § 36; M. Gobert, La jurisprudence source de droit triomphante mais menancée, RTD (1992) civ. 344; J. Esser, Grundsatz und Norm in der richterlichen Fortbildung des Privatrechts, Tübingen 1974; D. Simon, Die Unabhängigkeit des Richters, Darmstadt 1975, p. 68.

5 Vice versa, for the common law context, the answer might be different, cf. R. Cross, op. cit. For another view, cf. K.N. Llewellyn, The Normative, the Legal, and the Law Jobs: The Problem of Juristic Method, 49 Yale L.J. (1940), p. 1355.

${ }^{6} \S 132$ Abs. 4 GVG.

${ }^{7}$ Cf., e.g., G.C.R. Iglesias, Der EuGH und die Gerichte der Mitgliedstaaten - Komponenten der richterlichen Gewalt in der Europäischen Union, NJW 2000, 1889; K.-H. Ladeur, Richterrecht und Dogmatik - eine verfehlte Konfrontation?, KritV 1996, p. 77; F. Müller, R. Christensen, Juristische Methodik, Bd. 2, Berlin 2003, pp. 359-415. 
interpretation of a statue. Further emphasis be spent on the question as to whether or not the application of private law of European origin by national courts has additional impact on uniform interpretation.

\section{THE PRINCIPLES OF EQUALITY AND LEGAL CERTAINTY}

To the principle of equality is bequeathed the necessity of uniform interpretation and application of the law ${ }^{8}$. In Germany, the guarantee of legal certainty counts as a fundamental constitutional principle ${ }^{9}$, which has been established by the courts in the way of pursuing a uniform method in the actual application of the rules. Legal certainty is, together with the guarantee of substantive justice, one of the two component parts of the principle of the due course of law ${ }^{10}$. At the same time, it is a procedural objective ${ }^{11}$. Since the aim of substantial justice in individual cases and the guarantee of legal certainty can oppose each other, it may well be observed that this conflict is resolved in favour of legal certainty, means rather for the sake of the judicial system as a whole than for justice in an individual case. Legal certainty is a concept of legal policy, which taken by itself signifies nothing: only in the context of a constitutionally recognised order does it become a requirement to achieve the utmost clarity and rationality in the decision-making process.

The judiciary obtains that legitimacy so characteristic of any democratic state by the way in which judicial decisions are bound to the letter of the law. However, this observation does not reach very far, for the binding nature of both written and unwritten law (e.g., precedent) also encompasses the jurisdiction of the courts as to statutory interpretation and the further development of the law. In the words of the German Constitutional Court, a judge is bound by both the written as well as the unwritten law in order to guard against a too narrow positivistic approach being adopted: "Out of the positive rules of public authorities, there can occasionally arise an overabundance of law which has its source in the constitutional order taken in its entirety and may be seen to operate as a corrective to the written law; to find this is the task of the courts"12. The concept of a judge being bound only to the letter of the law presupposes the completeness of any positive legal order; in other

${ }^{8}$ Cf. R. Cross, op. cit.; N. MacCormick, Z. Bankowski, On Method and Methodology, [in:] Interpreting statutes. A Comparative Study, ed. N. MacCormick, Aldershot-Brookfield 1991 (1996), p. 9.

9 Article 20 Abs. 3 GG - cf. BVerfG 34, 269, 278 Soraya; BVerfGE 66, 116, 138 Walraff.

${ }^{10}$ BVerfG 34, 269, 278 Soraya. Cf. P. Badura, Staatsrecht, München 2015, Nr. D 50; Kommentar zum Grundgesetz, Hrsg. B. Schmidt-Bleibtreu, H. Hoffmann. H.-G. Henneke, Köln 2017, Article 20 Rn 57.

${ }^{11}$ A. Baumbach, W. Lauterbach, J. Albers, P. Hartmann, Zivilprozessordnung: ZPO, München 2017, Einl. III Rn 43.

${ }^{12}$ BVerfGE 34, 269, 287 Soraya. 
words, a solely theoretical situation. Although a judge must refrain from acting in an arbitrary fashion, it nevertheless remains his duty to bring full expression to the values represented in the constitutional order. In so doing he is expected to both recognise and evaluate the same which activity need not lack elements of his will as an individual. That a judge should be so given to creatively develop the law in such a way has never been contested ${ }^{13}$.

\section{LEGAL SYSTEM AND LEGAL METHOD}

The demands for legal certainty and equality before the law would seem to largely remain unfulfilled. Not only within the scope of indeterminate legal concepts, or when closing so-called loopholes in the law, but also where statutory texts are clearly expressed is there a great deal of judicial activity involving freedom of interpretation as well as entailing rapid developments in the law. For example, in the law of unfair competition, the dynamics and diversity of all conceivable situations are so great, that it has always been difficult to find clearly definable groups of cases conforming with the requirements of legal certainty, even where the courts' jurisdiction is exclusively case-related ${ }^{14}$. In addition, certain procedural court practices provide further potential for conflict-solving strategies ${ }^{15}$. For this reason, commentaries for the classification of case material are available ${ }^{16}$. Continental legal systems are not familiar with the Anglo-American common law concepts of binding precedent and stare decisis ${ }^{17}$. Alone the reference to the Anglo-American system does not lead one much further because continental judge-made law does not offer a comparable measure of certainty. In any case, there is at least even here the tendency to examine precedents when forming concrete rules of law and not to deviate from them without valid reason.

It is debatable whether this widely held opinion should be accepted in the light of the above-outlined constitutional principle. Might it not rather be the case that the traditional tenets of juridical thinking are so inseparably linked with the postulate of legal certainty, that only a systematically strict foundation on which to base a statement of reasons is justified. From the point of view of any individual

13 Cf. ibidem, 286.

${ }^{14}$ W. Hefermehl, Rechtsfortbildung im Wettbewerbsrecht, [in:] Richterliche Rechtsfortbildung, Hrsg. G. Reinhart, Heidelberg 1986, p. 331; O.F.F. von Gamm, Richterliche Rechtsfortbildung, 323, [in:] ibidem, p. 619.

15 B. Oppermann, Unterlassungsanspruch und materielle Gerechtigkeit, Tübingen 1993.

${ }^{16}$ For the law of unfair competition ref. H.-J. Ahrens, Der Wettbewerbsprozess, Köln 2005, Einl.

11; H. Köhler, J. Bornkamm, UWG, München 2017, Einl. UWG 2.4., 2.42 and passim.

${ }^{17}$ For comparative studies on legal method, cf. N. MacCormick, Z. Bankowski, op. cit., passim. 
subjected to the processes of law, the question is quite simply reduced to knowing how the judge will decide the case.

In other words, those requirements - which are essential when pronouncing actual legal rules - must be clearly recognisable. Legal method will be thereby advanced $^{18}$. However, the existence of a legal method that is universally valid has, from the perspective of legal theory, become doubtful ${ }^{19}$. The original problem centred on the conditions under which the production of law can be legitimately described as "proper" law. Later concerns reflected the conceivability of the unity and autonomy of any legal system, before moving on to consider the role of language and logic in legal argumentation or rather reasoning. Taken over a reasonably measurable period of time, no lasting satisfactory solution has been found ${ }^{20}$.

The policy concepts of legal certainty have therefore assumed divergent, partly antithetical tasks. In an ideal condition, absolute certainty of the law would no longer be at disposal - the elements of any given system are completely fixed: there are no more degrees of freedom ${ }^{21}$. This supposition would not be suitable for an analysis of concrete legal phenomena. Indeed, the legal concept of certainty does not suggest determinacy. Individuals or groups need the certainty and rationality of the law when attempting thereby to diminish their own risks owing to the fact that they are actually reducing their freedom of disposition in certain areas, e.g., through contractual stipulation. New kinds of options have themselves given rise to new uncertainties, which in turn have to be overcome so that "certainty" may rightly become an element of the dynamics of social change. Thereby it may be a paradox since the reflexivity of law together with legal certainty occasioned themselves to produce by their very nature uncertainty. This will lead in turn to uncertainty because the "securing of certainty" lies in the making available of legally institutionalised options and not in the direct and strict observance of the integrity of any particular object of legal protection. Such deliberations call for a further restriction: on the analysis of real connections between legal actions, the assumption of absolute certainty in law results in a paradox. In order to deal with uncertainty about future eventualities, just the probability of being able to predict the outcome of decisions is sufficient.

18 BVerfG 34, 269, 278 Soraya; BVerfGE 66, 116, 138 Walraff.

19 B. Rüthers, C. Fischer, A. Birk, Rechtstheorie, München 2015, §§ 20-24.

${ }^{20}$ Cf. J. Esser, Grundsatz und Norm in der richterlichen Fortbildung des Privatrechts, Tübingen 1964, p. 14, 141; N. Luhmann, Die Einheit des Rechtssystems, Rechtstheorie 14 (1983), p. 129; D. Simon, op. cit., p. 8, 90; G. Struck, Topische Jurisprudenz, Frankfurt 1971; B. Oppermann, Die Rezeption des amerikanischen Rechtsrealismus durch die deutsche Topikdiskussion, Frankfurt 1985, pp. 6-41, 120, 134; idem, Zur Argumentation im Recht: Entscheidungsfolgen als Rechtsgründe?, RabelsZ 1992, p. 553.

${ }^{21}$ U. Preuß, Sicherheit durch Recht, KritV 1989, pp. 3-4. 
The term "legal certainty" may, therefore, be used to describe a structure for the production of law which makes it possible for the observer to recognise rules of law and to use them to some extent. Thus, it should be possible to achieve propositions regarding the probable outcome of court proceedings - and which for a period may lay claim to validity. In this restricted sense, legal certainty can be spoken of as both a basic constitutional principle and a procedural objective ${ }^{22}$.

There remains a problem as to how to produce the certainty of the law and how the principle of equality can be complied with under these conditions. A potential solution could be either a doctrine of precedent or the application of uniform methodical criteria. In German tradition, the latter, the interpretatio logica, equipped as it is with an appearance of scientific exactitude, has proven to be a specific variable in the historical context of legal development in the nineteenth century ${ }^{23}$. Legal thinking in systems acquired its justification by promising to bring about equality before the law and legal certainty and to banish arbitrariness by the use of dogmatic means. Guarantee for this is provided by the so-called "conceptual jurisprudence" (Begriffsjurisprudenz) in so far as it re-interprets conflicts into questions for legal reasoning and makes application of law ideal for a sequence of steps which can be reconstructed at any time through being linked by a chain of unbroken deduction ${ }^{24}$. Since the decline of philosophical idealism, the promises of systems thinking have come to seem no longer trustworthy. Out of this critique arose - after post-war consolidation - the concepts of legal "topic" and "hermeneutic". As with the North American concept of "legal realism" - also conceived of as a scientific critique of "conceptual jurisprudence" (Begriffsjurisprudenz) - these opinions have been gaining in significance for some time ${ }^{25}$. The far-reaching renunciation of the belief in a body of law, in other words, a kind of disbandment of the conceptual system, was passed off as "problem thinking". The so-called "topic" appeared as an escape from an unfruitful choice between natural law and legal positivism ${ }^{26}$. Its perceived function was to counteract the static fixing of the law. The dichotomy of problem-oriented and conceptual thinking, hidden behind the heading "topic", used to be said to be the only truly meaningful question even for legal theory ${ }^{27}$. It should not remain unmentioned

${ }_{22}$ O. Weinberger, Norm und Institution. Eine Einführung in die Theorie des Rechts, Wien 1988, p. 34.

${ }_{23}^{23}$ F. Wieacker, Privatrechtsgeschichte der Neuzeit, Göttingen 1996, p. 322, 458.

${ }^{24}$ S. Simitis, Die Bedeutung von System und Dogmatik, AcP, p. 172, 131, 136.

${ }_{25}$ F. Wieacker, Gesetzesrecht und richterliche Kunstregel, JZ 1957, p. 711.

${ }^{26}$ H. Coing, Geschichte und Bedeutung des Systemgedankens in der Rechtswissenschaft, [in:] Gesammelte Aufsätze zu Rechtsgeschichte, Rechtsphilosophie und Zivilrecht, Bd. 1: 1947-1975, Frankfurt 1982, p. 191, 194, 206; M. Kriele, Theorie der Rechtsgewinnung, Berlin 1967, p. 114.

${ }^{27}$ R. Zippelius, Problemjurisprudenz und Topik, NJW 1967, p. 2229; F. Wieacker, Zur praktischen Leistung der Rechtsdogmatik, [in:] Hermeneutik und Dialektik II (Festschrift Gadamer), Hrsg. R. Bubner, Tübingen 1970, p. 311; J. Esser, Möglichkeiten und Grenzen des dogmatischen Denkens im modernen Zivilrecht, AcP 172 (1972), p. 97, 99, 114, 124. 
that practitioners, especially judges participated in this discussion because they saw in "topic" a method of understanding the object of interpretation, the law, which would meet the requirements of their work. However, that no-one any longer speaks about the "topical" or "hermeneutical" critique of legal method has done nothing since then to change the sweeping effect of unleashed judicial creativity in the production of law.

\section{INTERPRETATION AND PRECEDENT}

Obviously, interpretation is not just the revelation of meaning; the interpretation of law serves the convergence of the facts of a case and the applicable rules and is therefore essential in every case. In addition, as harmonised law, it must also be in accordance with the meaning of the EU premises. The interpretation according to the sense and purpose of a rule - as well named the objective-teleological method of interpretation - distances itself far from the law and its wording because it matches its subject with the purposes and aims of the statute against the background of an ever-changing world. At the same time, it becomes possible either to avoid or to eliminate any values in conflict with other parts of the legal system. Whereas the free form of interpretation used to be occasionally rejected, it is nowadays even considered to be the most elegant mode of interpretation of legal texts. Besides the above-mentioned advantages, it actually realises the conformity of the traditional body of civil law with the aims of the modern constitution as well as the direct unification or at least harmonization of European law.

There are, of course, certain inherent dangers in dealing freely with texts. It is important to establish that there is no universally acknowledged hierarchy regarding the various single methods of interpretation. At any rate, a certain priority of importance would be appropriate for the wording of a text, which results in the reverse conclusion that the borderline of a possible lexical meaning at the same time characterises the borderline between interpretation and further development of the law. For the German legal system, the techniques of interpretation are supposed to guarantee that the construction of a rule by a judge can be distinguished from the further development of the law. It is true that on the other side of this borderline there are still some methodical tools available, e.g., the analogy as well as further forms of the so-called "closing of legal loopholes", though much less precise. It must not be underestimated that the demand for such a border is befitting for judicial activity within a constitutional state. In this sense, it is about whether the establishing of equality before the law would be best achieved under an improved system. On the other hand, the doctrine of equity, no matter how welcome it may be in individual cases, is not a suitable means for attaining this end ${ }^{28}$.

\footnotetext{
${ }^{28}$ Cf. N. MacCormick, Z. Bankowski, op. cit.
} 
Precedents are not a source of law in the strict sense. In Germany, previous decisions of the same court or of other or higher courts are not legally binding, they rather provide an authoritative example for correct interpretation ${ }^{29}$. Practically, however, precedents at least of the Supreme Court are adopted by courts of lower instance. Although one might not disregard the right of the judge of lower instances to oppose the precedent, the appellate court system develops a factual force. Its practical effect comes close to the results of the common law stare decisis doctrine, could be analysed as a "persuasive authority" 30 . Its character is presumptively binding in the sense of a prognosis about the outcome of a judicial case.

\section{UNIFORM INTERPRETATION OF EUROPEAN LAW}

Against this background, a glance at the omnipresent import of private EU law might be permitted. The necessity of uniform interpretation is valued highly; although there are no instruments for its guarantee, except, of course, the very existence of the European Court and the foundation of its purpose in the European Treaty. An extensively employed doctrine of "direct effect" or "consistent interpretation" plays an important role in the various legal systems within Europe. It has to a large extent a decisive influence not only on the European Court of Justice but on the courts of the Member States likewise ${ }^{31}$. The situation for judges of the European as well as of national courts who are expected to construe transformed European secondary law or legislation in conformity with harmonised law of the Member States became a commonplace ${ }^{32}$, yet, within the internal market it is the guarantee for equality before the law ${ }^{33}$.

${ }^{29}$ K.P. Berger, To what extent should arbitrators respect domestic law? The German experience regarding the Law on Standard Terms, "Arbitration International" 2016, Vol. 32(2), p. 243. Cf. already: F. Bydlinski, Hauptpositionen zum Richterrecht, JZ 19853 (2002), p. 149; B. Oppermann, Unterlassungsanspruch ..., p. 307. For Switzerland cf. W.R. Schluep, op. cit., Rn 2475-2516.

${ }^{30}$ H. Fenge, op. cit., p. 109, 123; K.P. Berger, op. cit., p. 243, 250; B. Oppermann, Unterlassungsanspruch..., p. 307. Such intermediary position leaves room for further research, cf. D.F. Effer-Uhe, Die Bindungswirkung von Präjudizien: eine Untersuchung aus dem Blickwinkel von Prinzipientheorie und Fuzzy-Logik, Göttingen 2008.

${ }^{31}$ Cf. G. Betlem, The Doctrine of Consistent Interpretation - Managing Legal Uncertainty, “Oxford Journal of Legal Studies" 2002, Vol. 22(3), DOI: https://doi.org/10.1093/ojls/22.3.397, p. 397; F. Müller, R. Christensen, Juristische Methodik, Bd. 2, pp. 359-415.

${ }^{32}$ T. Stein, Richterrecht wie anderswo auch? Der Gerichtshof der Europäischen Gemeinschaften als ,Integrationsmotor“, [in:] Richterliche Rechtsfortbildung, p. 625.

33 ECJ, 26.01.2010, Case C-555/07 Kücükdeveci, stresses the matter that if a EU directive gives expression to a general principle (e.g., non-discrimination on the grounds of age), the principle is to be applied and this even in proceedings between individuals under long established national law: national judges must not apply any conflicting legal provisions contrary to the general principle expressed by the directive. 
That the interpretation of transformed EU secondary legislation should in any way still depend on EU directives after transformation into the law of a Member State, lies in the fundamental general principles of the Community, especially in that of the direct effect of an EU directive ${ }^{34}$, in the principle of the supremacy of European law $^{35}$ as well as in the principle of a state being liable for damage arising out of behaviour opposed to the EU-Treaty ${ }^{36}$. Similar rights are guaranteed to European citizens largely by the national courts. Each of these principles obliges national judges to observe the intended purposes and aims of the European Union even when applying the law of a Member State ${ }^{37}$. This has resulted in binding consequences for national legal methods.

With regard to the interpretation of EU law, the judge of a Member State may not only use the methods of interpretation of his own legal system, he must also construe rules in conformity with EU standards. As a matter of procedural law, this proposition would not be plausible by any means; for the European Court of Justice assumes that national courts are autonomous both in ordinary as well as in summary proceeding ${ }^{38}$. But where there is autonomy of procedure, the court of a Member State may then operate in the usual manner even when Community law is being applied. This follows from the principle of lex fori.

Besides the difficulties deriving from the diversity of languages and from the problems of translation, there is a further problem insofar as even the national legal methods display not inconsiderable differences. German methodology makes a strict distinction between the interpretation and the further development of law, which is at least maintained in theory as well as in judicial opinion. The French have not taken up this differentiation in quite the same way; neither did the European Court of Justice ${ }^{39}$.

With respect to German legal method, a further problem regarding the doctrine of consistent interpretation concerns the hierarchy of methods. Although recent German legal method had admittedly been criticised for lacking a binding element, the exact wording of a rule can and should normally enjoy a certain priority in observation. As far as the "European method" is concerned, the opposite is usually the case. Because there are no obligations imposed on translations of the various

${ }^{34}$ ECJ, Slg 1963, 1 - Van Gend \& Loos. Cf. G.C.R. Iglesias, op. cit., NJW 2000, 1889, 1890.

35 ECJ, Slg 1978, 679 - Simmenthal.

36 ECJ, Slg 1991, I-5357 - Francovitch; Slg., 1996, I-1029 - Brasserie de pêcheur.

37 ECJ, 26.01.2010, Case C-555/07 Kücükdeveci.

${ }^{38}$ G.C.R. Iglesias, op. cit., NJW 2000, 1889, 1892-1894. Cf. ECJ, 26.01.2010, Case C-555/07 Kücükdeveci.

39 R. Wank, Die Rechtsfortbildung durch den Europäischen Gerichtshof, [in:] Arbeitsgesetzgebung und Arbeitsrechtsprechung, Hrsg. F. von Farthmann, P. Hanau, U. Isenhardt, Berlin 1995, p. 633, 635; W. Dänzer-Vanotti, Unzulässige Rechtsfortbildung des Europäischen Gerichtshofs, RIW 1992, p. 733. 
working languages of the EU, the word is not able to take central position. For mainly legal reasons, priority is given to the objective-teleological method, i.e., to the "spirit" of a directive or regulation ${ }^{40}$. The syncretism of methods of interpretation has been surrendered in favour of the most inexact or even suspicious interpretation method of them all. Amidst the requirements of legal certainty and uniformity of application of the law this situation remains problematic as long as there is no separate theoretical basis ${ }^{41}$. As a critical consequence of this, an almost certainly augmented European Court of Justice sets the limits on the creation of law by judicial decision or precedents ${ }^{42}$, which will be neither a remedy for the problems outlined nor would it be to be found in comparative law.

\section{CONCLUSIONS}

German conceptual jurisprudence (Begriffsjurisprudenz) was a science in a purely legal sense only and as such a residue of the $19^{\text {th }}$ century. Its virtue has been that its very existence to a large extent continues to assert the unlawfulness of arbitrary rules. On its part again, it acquires justification from the general postulate of legal certainty and therefore also from the principle of equality thereby ensuring equality before the law for all those who are subject to the law. The means to this end are re-inforced by the help of far-reaching codification and much improved methodical tools. In this way, the exact wording of the regulation becomes the hub of attention and the distinction between interpretation and the development of the law through judge-made law becomes easily recognisable. Acceptance of the thereby created "dogmatism" was achieved through the conception of a systematically comprehensive legal reconstruction of reality. Consequently, precedents are not a source of law in the strict sense. In Germany, previous decisions of the same court or of other or higher courts are not legally binding; rather they function as a persuasive authority.

Unfortunately, the disadvantage of this system lies in the loss of its (theoretical) basis. Private law has indeed developed increasingly further away from the great systematic statutory works of history. By way of the interpretation and development of the law, judicial practice has extended legal development in accordance with market needs and modern notions of, e.g., life in a social community or consumer protection.

40 T. Stein, op. cit., p. 619, 627.

${ }^{41}$ Cf. Savigny's idealistic conception of a system, cf. C. von Savigny, System des heutigen Römischen Rechts I, Berlin 1840, DOI: https://doi.org/10.1515/9783111692302, p. 206.

${ }^{42}$ K.H. Ladeur, op. cit., p. 77, passim. 
The legislator has followed suit with an increase in the amount of regulations outwith and independent of the systematic edifice of the German Civil Code. European secondary legislation has only accelerated this process so that the national legislator would not be able to act any differently, even if he wanted to.

Before any potential development of a uniform European method is likely to happen, comparative law is offering an interim solution, albeit one that is forensically not very satisfying insofar as it lacks any binding nature necessary to perceive legitimacy. Over the last few decades, judicial involvement in consistent interpretation and further development of the law, maybe even judge-made law by precedents itself, has been increasing in significance. In this sense precedents and stare decisis are in tendency substituting the interpretatio logica in quite some German court practice. However, unlike the common law, continental law lacks the requisite methodical tools. Against this background, the continental systems would do well to consider using more case-law method just as the common law has turned more and more to the legislative rule - and not just in the wake of the assumption of the primary and secondary legislation of the European Union.

Perhaps in the future there will once more be a "European Common Law", as there used to be before the great codification movements of the $19^{\text {th }}$ century. Either common principles of interpretation or a new doctrine of precedents would be necessary to achieve this end. Though, as long as there is no European method, neither the case law of the European Court of Justice nor consistent interpretation of the courts of the Member States contribute very much towards the principles of equality before the law and the certainty of law.

\section{REFERENCES}

Ahrens H.-J., Der Wettbewerbsprozess, Köln 2005.

Bach L., Répertoire de droit civil, Paris 2009.

Badura P., Staatsrecht, München 2015.

Baumbach A., Lauterbach W., Albers J., Hartmann P., Zivilprozessordnung: ZPO, München 2017.

Berger K.P., To what extent should arbitrators respect domestic law? The German experience regarding the Law on Standard Terms, "Arbitration International" 2016, Vol. 32(2).

Betlem G., The Doctrine of Consistent Interpretation - Managing Legal Uncertainty, "Oxford Journal of Legal Studies" 2002, Vol. 22(3), DOI: https://doi.org/10.1093/ojls/22.3.397.

Bydlinski F., Hauptpositionen zum Richterrecht, JZ 19853 (2002).

Coing H., Geschichte und Bedeutung des Systemgedankens in der Rechtswissenschaft, [in:] Gesammelte Aufsätze zu Rechtsgeschichte, Rechtsphilosophie und Zivilrecht, Bd. 1: 1947-1975, Frankfurt 1982.

Cross R., Precedent in English Law, Oxford 1977.

Dänzer-Vanotti W., Unzulässige Rechtsfortbildung des Europäischen Gerichtshofs, RIW 1992.

Effer-Uhe D.F., Die Bindungswirkung von Präjudizien: eine Untersuchung aus dem Blickwinkel von Prinzipientheorie und Fuzzy-Logik, Göttingen 2008.

Esser J., Grundsatz und Norm in der richterlichen Fortbildung des Privatrechts, Tübingen 1974. 
Esser J., Grundsatz und Norm in der richterlichen Fortbildung des Privatrechts, Tübingen 1964.

Esser J., Möglichkeiten und Grenzen des dogmatischen Denkens im modernen Zivilrecht, AcP 172 (1972).

Fenge H., Der Richterspruch als Rechtsquelle, [in:] International Legal Studies, ed. B.H. Oppermann, Bd. 1, Halle 2009.

Gamm O.F.F. von, Richterliche Rechtsfortbildung, 323, [in:] Richterliche Rechtsfortbildung, Hrsg. G. Reinhart, Heidelberg 1986.

Gobert M., La jurisprudence source de droit triomphante mais menancée, RTD (1992) civ. 344.

Hefermehl W., Rechtsfortbildung im Wettbewerbsrecht, [in:] Richterliche Rechtsfortbildung, Hrsg. G. Reinhart, Heidelberg 1986.

Iglesias G.C.R., Der EuGH und die Gerichte der Mitgliedstaaten - Komponenten der richterlichen Gewalt in der Europäischen Union, NJW 2000, 1889.

Kommentar zum Grundgesetz, Hrsg. B. Schmidt-Bleibtreu, H. Hoffmann. H.-G. Henneke, Köln 2017.

Köhler H., Bornkamm J., UWG, München 2017.

Kriele M., Theorie der Rechtsgewinnung, Berlin 1967.

Ladeur K.H., Richterrecht und Dogmatik - eine verfehlte Konfrontation?, KritV 1996.

Llewellyn K.N., The Normative, the Legal, and the Law Jobs: The Problem of Juristic Method, 49 Yale L.J. (1940).

Luhmann N., Die Einheit des Rechtssystems, Rechtstheorie 14 (1983).

MacCormick N., Bankowski Z., On Method and Methodology, [in:] Interpreting statutes. A Comparative Study, ed. N. MacCormick, Aldershot-Brookfield 1991 (1996).

Montesquieu C., De L'esprit des lois, Vol. XI, Ch. 6.

Müller F., Christensen R., Juristische Methodik, Bd. 1, Berlin 2009.

Müller F., Christensen R., Juristische Methodik, Bd. 2, Berlin 2003.

Oppermann B., Die Rezeption des amerikanischen Rechtsrealismus durch die deutsche Topikdiskussion, Diss., Frankfurt 1985.

Oppermann B., Unterlassungsanspruch und materielle Gerechtigkeit, Tübingen 1993.

Oppermann B., Zur Argumentation im Recht: Entscheidungsfolgen als Rechtsgründe?, RabelsZ 1992.

Preuß U., Sicherheit durch Recht, KritV 1989.

Rüthers B., Fischer C., Birk A., Rechtstheorie, München 2015.

Savigny C. von, System des heutigen Römischen Rechts I, Berlin 1840,

DOI: https://doi.org/10.1515/9783111692302.

Schluep W.R., Einladung zur Rechtstheorie, Bern 2008.

Simitis S., Die Bedeutung von System und Dogmatik, AcP.

Simon D., Die Unabhängigkeit des Richters, Darmstadt 1975.

Stein T., Richterrecht wie anderswo auch? Der Gerichtshof der Europäischen Gemeinschaften als „Integrationsmotor", [in:] Richterliche Rechtsfortbildung, Hrsg. G. Reinhart, Heidelberg 1986.

Struck G., Topische Jurisprudenz, Frankfurt 1971.

Wank R., Die Rechtsfortbildung durch den Europäischen Gerichtshof, [in:] Arbeitsgesetzgebung und Arbeitsrechtsprechung, Hrsg. F. von Farthmann, P. Hanau, U. Isenhardt, Berlin 1995.

Weinberger O., Norm und Institution. Eine Einführung in die Theorie des Rechts, Wien 1988.

Wieacker F., Gesetzesrecht und richterliche Kunstregel, JZ 1957.

Wieacker F., Privatrechtsgeschichte der Neuzeit, Göttingen 1996.

Wieacker F., Zur praktischen Leistung der Rechtsdogmatik, [in:] Hermeneutik und Dialektik II (Festschrift Gadamer), Hrsg. R. Bubner, Tübingen 1970.

Zippelius R., Problemjurisprudenz und Topik, NJW 1967. 


\section{STRESZCZENIE}

W artykule poruszono kwestię roli precedensów w niemieckiej praktyce prawniczej. W europejskiej tradycji kontynentalnej stanowienie prawa leży w kompetencji władzy ustawodawczej, podczas gdy władza sądownicza polega na stosowaniu prawa. Precedens w systemie kontynentalnym nie stanowi źródła prawa sensu stricto, czyli formalnego źródła prawa. W systemie tym w celu zapewnienia jednolitości prawa, a ostatecznie - pewności prawa, sądy dokonują jednolitej interpretacji przepisów prawnych. Wskazać należy, że w ostatnich latach wzrosło dokonywanie przez sędziów spójnej interpretacji przepisów i przyczynianie się tym samym do rozwoju prawa. Oznacza to, że jednolita wykładnia dokonywana przez sądy może być traktowana jako precedens. W tym znaczeniu coraz częściej w sądach niemieckich precedens i stare decisis zastępują wykładnię logiczną.

Słowa kluczowe: precedens; słuszność prawa; niemiecki system prawny; metoda prawna; wykładnia logiczna 